\title{
(JOŠ) O UJEDNAČAVANJU SUDSKE PRAKSE U GRAĐANSKIM PREDMETIMA
}

\author{
Doc. dr. sc. Dejan Bodul* \\ Dr. sc. Jelena Čuveljak** \\ Doc. dr. sc. Sanja Grbić***
}

\author{
UDK: 347.91/.95:341.231.14(497.5) \\ https://doi.org/10.30925/zpfsr.41.1.6 \\ Ur.: 13. siječnja 2020. \\ Pr.: 4. veljače 2020. \\ Izvorni znanstveni rad
}

\begin{abstract}
Sažetak
Ideal je sudskog postupka visoki stupanj predvidljivosti, a to nije ništa drugo nego stabilna i ujednačena sudska praksa. Naime, građani i poslovni subjekti koji idu na sud zbog identičnih činjeničnih okolnosti moraju dobiti istu presudu, a sudovi jedne države moraju rješavati identična pravna pitanja na isti način, bez obzira na to gdje se nalazili. S druge strane, u osnovi pravnog standarda neovisnosti sudbene vlasti nalazi se sloboda individualnog sudca od svih utjecaja koji bi mu priječili da odlučuje samo ex lege, na temelju svoje savjesti te in concreto, pri rješavanju konkretnih predmeta. Dakle, kako je malo, ako ih uopće ima, praktičara, teoretičara i kreatora pravne misli koji ne bi ceteris paribus željeli veći stupanj ujednačene sudske prakse, spuštajući se na empirijsku razinu autori uočavaju kako je osiguranje dosljedne primjene zakona u praksi iznimno zahtjevan posao. Iako su na raspolaganju različiti metodološki pristupi za izučavanje ovoga složenog problemskog pitanja, nastojanja su usmjerena $u$ pravcu analize pozitivnih rješenja kao i prakse ESLJP-a, a sve radi mogućih prijedloga.
\end{abstract}

Ključne riječi: ujednačavanje prakse; novi Zakon o parničnom postupku; članak 6. ESLJP-a.

\section{OKVIR ZA RASPRAVU}

Ni jednom pravnom sustavu nije strano da u situacijama činjenično i pravno naizgled sličnim, a koje su rijetko istovjetne, sudovi donose različite odluke. Stoga, iako u stvarnosti nedostižna, ujednačenost kao normativni dezideratum nikako ne prestaje biti relevantna. Ipak, iako se o ujednačenoj sudskoj praksi, striktno govoreći, može

* Dr. sc. Dejan Bodul, docent, Sveučilište u Rijeci, Pravni fakultet; dbodul@pravri.hr.

** Dr. sc. Jelena Čuveljak, sutkinja Visokog trgovačkog suda Republike Hrvatske; jelena. cuveljak@gmail.com.

*** Dr. sc. Sanja Grbić, docentica, Sveučilište u Rijeci, Pravni fakultet; sgrbic@pravri.hr.

Ovaj rad je financiran sredstvima Sveučilišta u Rijeci za projekt ZP UNIRI 4/19. 
govoriti samo kao o normativnom idealu, doktrina ističe kako načini ujednačavanja sudske prakse trebaju postići ravnotežu s obzirom na to da, s jedne strane, ne smiju narušavati neovisnost pravosuđa, a s druge strane, mehanizmi ujednačavanja sudske prakse moraju biti učinkoviti. Cilj je analizirati koliko i kako zakonodavac rješava problem ujednačavanja sudske prakse imajući na umu kako navedena rasprava uključuje veći broj tema koji nisu manje važne od onih koje su ovdje spomenute (česte izmjene zakona koje rezultiraju nepreciznim i neusklađenim normama, pravne praznine u pojedinim odredbama zakona, veliki broj predmeta u radu, nedostatak stručnih suradnika koji bi pomagali u izradi sudskih odluka, faktični problem prostora i dostupnosti relevantne literature).

\section{ULOGA USTAVNOG SUDA RH ZA UJEDNAČAVANJE SUDSKE PRAKSE (I RASPRAVE)}

Ustavni sud RH normativno nema u nadležnosti usklađivanje sudske prakse. Štoviše, u nizu je svojih odluka odbio ustavnu žalbu pritom naglasivši da nije sud, tzv. „četvrte instance” te da nije njegov zadatak provjeravati svaku primjenu materijalnog prava, već samo takve povrede tog prava koje imaju značenje povreda Ustavom i Konvencijom zajamčenih ljudskih prava i temeljnih sloboda. Ipak judikatura i doktrina govore o neformalnom utjecaju Ustavnog suda na jednako tumačenje i primjenu prava te jedinstvenost sudske prakse. Razlog se potencijalno pronalazi u činjenici kako održavanje suprotstavljenih sudskih odluka potencijalno može dovesti do stanja pravne nesigurnosti koje bi vjerojatno oslabilo povjerenje javnosti u pravosudni sustav, a to je povjerenje nesumnjivo jedna od ključnih komponenti države utemeljene na vladavini prava koju osigurava i Ustavni sud. ${ }^{.}$Štoviše, iako su u nizu odluka visoki sudovi pokazali eksplicitnu spremnost da, suglasno s odredbom članka 31. stavak 1. UZOPUS-a, ${ }^{2}$ slijede u ponovnom postupku pravne razloge iznesene u ukidnoj odluci Ustavnog suda, postupak vezan za pravno shvaćanje iz ukidne odluke Ustavnog suda može biti predmet problematiziranja. Naime, kako članak 31. spomenutoga Zakona navodi da su odluke i rješenja Ustavnog suda obvezatne pa se postavlja pitanje mora li sud odlučivati u skladu s tim razlozima, ili to znači samo da je te razloge dužan uzeti u obzir pri odlučivanju u ponovnom postupku, ali da ne mora svoju odluku

1 Exempli causa, o odluci broj U-III - 354/2016 od 30. ožujka 2017. Ustavni je sud riješio dvojbu vezanu za tražbine koje nisu prijavljene u postupku predstečajne nagodbe. Naime, u tom je predmetu podnositelju ustavne tužbe ranije osporenim rješenjem Visoki trgovački sud ocijenio da je rješenje Trgovačkog suda u Zagrebu doneseno sukladno s mjerodavnim odredbama Zakona o financijskom poslovanju i predstečajnoj nagodbi. U konkretnom se slučaju ne radi o tražbini koja je priznata u postupku predstečajne nagodbe, niti je obuhvaćena predstečajnom nagodbom, niti je riječ o tražbini koja je osporena u postupku predstečajne nagodbe, zbog čega je podnositelj izgubio procesnu legitimaciju za vođenje parničnog postupka. Podnositelj nije, kao vjerovnik, pravodobno prijavio svoje potraživanje prema dužniku (tuženiku) i nije sudjelovao u postupku radi sklapanja predstečajne nagodbe nad dužnikom. Stoga protekom roka za prijavu potraživanja u tom postupku, podnositelj više nije mogao voditi predmetni parnični postupak, slijedom čega je tužba odbačena.

2 Ustavni zakon o Ustavnom sudu Republike Hrvatske, Narodne novine, br. 99/99., 29/02., $49 / 02$. 
zasnovati na tim razlozima, iznoseći razloge zašto nije prihvatio to shvaćanje. Riječ je, dakle, u doktrinarnim raspravama o pitanju do koje mjere razrađeno i konkretizirano obrazloženje odluka Ustavnog suda treba omogućiti sudovima da u pojedinim ponovljenim postupcima otklone nedostatke na koje im se htjelo ukazati u odlukama tog suda. Od odgovora na ovo pitanje ovisio bi i odgovor na pitanje koliko Ustavni sud smije i treba preuzeti na sebe funkciju najviše sudske instance, treba li, npr. u parničnim predmetima (faktički i pravno) nastupati kao sud četvrtog stupnja. ${ }^{3}$ Za to bi mogli biti korisni standardi koje je razvio ESLJP, a koji naznačuju da žalbeni sudovi nisu izuzeti iz obveze da svoje odluke obrazlože kako bi ih stranke u postupku shvatile. ${ }^{4}$ Međutim, ovisno o kontekstu, ovaj se cilj može ostvariti i pružanjem manje podrobnih obrazloženja. Žalbeni sud, primjerice, može jednostavno odlukom kojom odbacuje žalbu potvrditi presudu nižeg suda, čime implicitno odbacuje argumente podnositelja zahtjeva. ${ }^{5} \mathrm{~S}$ druge strane, žalbeni sud može nadomjestiti manjkavo obrazloženje nižeg suda tako što će pružiti dostatno obrazloženje i tako podnositelju zahtjeva omogućiti da shvati odluku izrečenu u njegovom predmetu. ${ }^{6}$ Drugostupanjski sud može se i ne složiti s obrazloženjem odluke suda prvog stupnja, pa u svojoj presudi, iako je u konačnici odluka za stranku identična, pružiti drukčije obrazloženje uz drukčiju primjenu materijalnog prava. No, kada Ustavni sud odlučuje o pojedinim pitanjima koja su različito riješena pred sudovima, takva odluka nedvojbeno utječe na ujednačenu primjenu prava. ${ }^{7}$

\section{ULOGA ESLJP-A ZA UJEDNAČAVANJE SUDSKE PRAKSE (I RASPRAVE)}

Prema sudskoj praksi ESLJP-a jedno od temeljnih načela vladavine prava je načelo pravne sigurnosti. Ono je implicitno sadržano u Konvenciji. ${ }^{8}$ Ako nema mehanizma koji bi osigurao dosljednost, proturječne odluke u sličnim predmetima koje je donio isti sud, posebice kada je on zadnja instanca na kojoj se odlučuje o dotičnom predmetu, one mogu dovesti do povrede tog načela i potkopati uvjerenje javnosti u sustav pravosuđa. ${ }^{9}$ To je povjerenje jedna od bitnih sastavnica države utemeljene na vladavini prava. Ipak funkcija Europskog suda za ljudska prava (dalje u tekstu: ESLJP), u načelu, nije usklađivanje različitih odluka domaćih sudova, čak i ako su donesene

3 Podrobnije, Mihajlo Dika i Ivana Martinović, Analiza uticaja odluka Ustavnog suda Crne Gore na sistem redovnih sudova sa posebnim osvrtom na odnos Ustavnog i Vrhovnog suda Crne Gore (Strasbourg: Savjet Evrope, 2018.), 50 et seq.

4 Stoga je novelom ZPP-a iz 2019. (Zakon o izmjenama i dopunama Zakona o parničnom postupku, Narodne novine, br. 70/19.) ukinuto pravilo na temelju kojeg je bila propisana mogućnost da drugostupanjski sud, ako odbija žalbu presudom, u obrazloženju posebno ne obrazlaže presudu u slučaju ako prihvaća činjenično stanje utvrđeno prvostupanjskom presudom, kao i primjenu materijalnog prava.

5 Vidaković protiv Crne Gore, presuda, 24. svibnja 2016., br. 27524/06.

6 Hirvisaari protiv Finske, presuda, 27. rujna 2001., br. 49684/99.

7 Vidi supra fusnota 4.

8 Beian protiv Rumunjske (br. 1), presuda, 6. prosinca 2019., br. 30658/05.

9 Vidi, Tudor Tudor protiv Rumunjske, presuda, 24. ožujka 2009., br. 21911/03, Iordan Iordanov i ostali protiv Bugarske, presuda, 2. srpnja 2009. br. 23530/02. 
u naizgled sličnim ili povezanim postupcima jer on mora poštovati neovisnost tih sudova. Ovlasti ESLJP-a ograničene su na provjeru poštuje li država članica obveze u području ljudskih prava koje je preuzela pri pristupanju Konvenciji. Pored toga, ESLJP uvažava različitost europskih pravnih i pravosudnih sustava te ih nije dužan standardizirati. Judikatura ESLJP-a naznačuje kako se razlike u sudskoj praksi između domaćih sudova ili unutar istog suda ne mogu, same po sebi, smatrati suprotnima Konvenciji. ${ }^{10}$ Štoviše, zahtjev pravne sigurnosti i zaštite legitimnih očekivanja ne uključuje pravo na utvrđenu/stečenu sudsku praksu ${ }^{11}$ jer razvoj sudske prakse nije sam po sebi u suprotnosti s pravilnim djelovanjem pravosudnog sustava, ${ }^{12}$ budući da bi nepostojanje dinamičnog i razvojnog pristupa spriječilo reforme ili poboljšanje. ${ }^{13}$ Međutim, može se dogoditi da u nekim predmetima razlike u sudskoj praksi dovedu do utvrđivanja povrede članka 6. stavak 1. Tu je pristup ESLJP-a različit ovisno o tome javljaju li se te razlike u sklopu iste vrste sudova ili između dvije različite vrste sudova koji su međusobno potpuno neovisni. Također, ako odstupanje od dosljednosti sudske prakse „nema objektivno i razumno opravdanje”, tj. ako ne slijedi legitimni cilj ili ako ne postoji „razuman odnos proporcionalnosti između upotrijebljenih sredstava i cilja kojem se teži," 14 odstupanje može prouzročiti različito postupanje u pogledu uživanja zajamčenih prava i posljedično rezultirati povredom članka 14 . Konvencije. ${ }^{15}$ ESLJP svakako ističe važnost država da uspostave mehanizam kojima se osigurava konzistentnost/ujednačenost u postupanju suda i usuglašenost sudske prakse. Dakle, države potpisnice odgovorne su organizirati svoj pravni sustav tako da se izbjegne donošenje presuda koje nisu međusobno usuglašene. ${ }^{16,17}$

Nadalje, u ovom radu će biti analizirani neki važniji predmeti u kojima je ESLJP došao do prethodno spomenutih zaključaka.

U predmetu Nejdet Sahin i Perihan Sahin protiv Turske ${ }^{18}$ podnositelji zahtjeva tvrdili su da su postupci pred nacionalnim sudovima bili nepravični zbog proturječnih odluka koje su donijeli ti sudovi te tako doveli do povrede članka 6. Sin je podnositelja bio vojni pilot koji je poginuo u avionskoj nesreći dok je prevozio vojne trupe. Podnositelji su podnijeli zahtjev za mirovinom u skladu sa Zakonom br. 3713, koji se odnosio na borbu protiv terorizma. Dodijeljena im je mjesečna ratna vojna invalidska mirovina te paušalni iznos koji je jednak zbroju trideset plaća najvišeg državnog službenika. Do takvog izračuna mirovine došlo je jer je turski mirovinski fond utvrdio kako smrt sina podnositelja nije bila prouzročena terorističkim aktom

10 Nejdet Şahin i Perihan Şahin protiv Turske, presuda, 20. listopada 2011., br. 13279/05 te Grkokatolička župa Lupeni i drugi protiv Rumunjske, presuda, 29. studeni 2016., br. 76943/11.

11 Unédic protiv Francuske, presuda, 18. prosinca 2008., br. 20153/04.

12 Grkokatolička župa Lupeni i drugi protiv Rumunjske, presuda, 29. studeni 2016., br. 76943/11.

13 Nejdet Şahin i Perihan Şahin protiv Turske, presuda, 20. listopada 2011., br. 13279/05, Albu i drugi protiv Rumunjske, presuda, 10. svibnja 2012., br. 34796/09

14 Marckx protiv Belgije, presuda, 13. lipnja 1979., br. 6833/74.

15 Beian protiv Rumunjske, presuda, 6. prosinca 2007., br. 30658/05.

16 Nejdet Sahin i Perihan Sahin protiv Turske, presuda, 20. listopada 2011., br. 13279/05.

17 Podrobnije, Vijeće Evrope/Europski sud za ljudska prava, Vodič kroz čl. 6. Konvencije-Pravo na pravično suđenje (građanskopravni aspekt), 2018., Vodiči kroz sudsku praksu dostupni su na mrežnoj stranici: www.echr.coe.int.

18 Nejdet Sahin i Perihan Sahin protiv Turske, presuda, 20. listopada 2011., br. 13279/05. 
već zbog toga što se njegov zrakoplov srušio iz nepoznatog razloga. Podnositelji su uložili žalbu protiv te odluke Upravnom sudu koji ju je odbacio smatrajući da ona potpada pod nadležnost Vrhovnog vojnog upravnog suda. Vrhovni vojni upravni sud odbacio je njihov zahtjev. Podnositelji su podnijeli žalbu protiv te presude tvrdeći da su pred Vrhovnim vojnim upravnim sudom donesene četiri odluke koje su donijeli redovni upravni sudovi u vezi sa zahtjevima sličnima zahtjevu podnositelja. U tim su odlukama sudovi presudili u korist podnositelja zahtjeva. Međutim, njihova je žalba odbijena kao neutemeljena. U zahtjevu koji su podnijeli ESLJP-u podnositelji su naveli kako je postupak pred nacionalnim sudovima bio nepravičan te da je mogućnost da ista činjenica može dovesti do različite pravne ocjene jednog suda od drugog $u$ suprotnosti s načelima jednakosti pred zakonom i dosljedne primjene zakona. Oni su istaknuli da su obitelji žrtava koje su poginule u istoj zrakoplovnoj nesreći kao i njihov sin podnijele zahtjeve koji su slični njihovom zahtjevu i da su dobile spor pred redovnim upravnim sudovima. Vijeće ESLJP-a smatralo je da njegov zadatak nije uspoređivati različite odluke domaćih sudova, čak iako su donesene u očigledno sličnim postupcima jer ono mora poštovati neovisnost tih sudova. Stoga je smatralo da nije došlo do povrede članka 6.

U postupku pred Velikim vijećem ESLJP je istaknuo kako on ne zamjenjuje nacionalne sudove te da je na nacionalnim vlastima, posebno sudovima rješavanje problema tumačenja zakonodavstva. Njegova je uloga ispitati jesu li učinci takvoga tumačenja u skladu s Konvencijom. ${ }^{19}$ ESLJP ne uspoređuje različite odluke nacionalnih sudova, čak ni one koje su donesene u sličnim postupcima. On mora poštovati neovisnost tih sudova. Nadalje, mogućnost proturječnih sudskih odluka po njemu je značajka svojstvena bilo kojem sudskom sustavu koji počiva na mreži prvostupanjskih i žalbenih sudova koji odlučuju u sklopu svoje teritorijalne nadležnosti. Takve se nepodudarnosti mogu pojavljivati u sklopu suda i nisu suprotne Konvenciji. ${ }^{20}$ ESLJP je ovdje iznio kriterije koje ispituje kada odlučuje pod kojim uvjetima proturječne odluke nacionalnih vrhovnih sudova dovode do povrede članka 6. Tako ispituje postoje li duboke i dugoročne razlike u sudskoj praksi vrhovnog suda, predviđa li nacionalno zakonodavstvo mehanizme za prevladavanje tih nedosljednosti, primjenjuju li se ti mehanizmi i koji su učinci njihove primjene. Pored duboke i dugoročne prirode nedosljednosti, smatra se i da pravna nesigurnost koja je rezultat nedosljednosti u praksi sudova i nedostatak mehanizama za rješavanje proturječnih odluka dovode do povrede prava na pravično suđenje. ESLJP je više puta istaknuo važnost uspostavljanja mehanizama kojima bi se osigurala dosljednost i jedinstvenost sudske prakse. Istaknuo je i da je odgovornost država da organiziraju svoje pravne sustave na takav način da se izbjegne usvajanje proturječnih presuda. ${ }^{21}$ Ocjenjivanje okolnosti predmeta koje ispituje ESLJP uvijek se temelje na načelu pravne sigurnosti koje je implicitno u svim člancima Konvencije i predstavlja jedno od temeljnih načela

19 Kuchoglu protiv Bugarske, presuda, 10. svibnja 2007., br. 48191/99 i Işyar protiv Bugarske, presuda, 20. studeni 2008., br. 391/03.

20 Santos Pinto protiv Portugala, presuda, 20. svibnja 2008., br. 39005/04.

21 Vrioni i ostali protiv Albanije, presuda, 24. ožujka 2009., br. 2141/03, Mullai i ostali protiv Albanije, presuda, 23. ožujka 2010., br. 9074/07 i Brezovec protiv Hrvatske, presuda, 29. ožujka 2011., br. 13488/07. 
vladavine prava. Nesigurnost, bilo da je pravna ili administrativna ili ukoliko proizlazi iz prakse koje primjenjuju nadležne vlasti, čimbenik je koji se mora razmotriti kada se ispituje postupanje države. Ponavlja da se pravo na pošteno suđenje mora tumačiti u svjetlu Preambule Konvencije u kojoj se izjavljuje da je vladavina prava dio zajedničkog nasljeđa država ugovornica. Jedan od temeljnih aspekata vladavine prava načelo je pravne sigurnosti koje jamči izvjesnu stabilnost pravnih situacija i doprinosi povjerenju javnosti u sudove. S druge strane, dugotrajnost proturječnih sudskih odluka može stvoriti stanje pravne nesigurnosti koje je po prirodi takvo da smanjuje povjerenje javnosti u pravosudni sustav. Takvo je povjerenje jedan od osnovnih elemenata države utemeljene na vladavini prava. Međutim, uvjeti pravne sigurnosti i zaštita legitimnog povjerenja javnosti ne dodjeljuju stečeno pravo na dosljednost sudske prakse. ${ }^{22}$ Razvoj sudske prakse nije po sebi suprotan ispravnom administriranju pravde budući da bi neodržavanje dinamičnog i evolucijskog stajališta stvorilo rizik od sprječavanja reforme ili poboljšanja. ${ }^{23}$ ESLJP je ovdje istaknuo kako se ovaj predmet razlikuje od onih koje je ispitivao u prošlosti jer pitanje o kojemu se raspravlja nisu proturječne odluke u sudskoj praksi sudova posljednje instance u sklopu iste grane sudskog sustava, nego nepodudarnost između presuda dviju hijerarhijski nepovezanih, različitih i neovisnih vrsta sudova. Imajući u vidu kriterije i načela utvrđena navedenom sudskom praksom, ESLJP smatra kako oni ne mogu biti preneseni na ovaj predmet jer se on bitno razlikuje od njih. Stoga je u svjetlu posebnih okolnosti predmeta ispitivao postoje li proturječne sudske odluke. Tako je istaknuo kako se mora izbjegavati bilo koje neopravdano miješanje u vršenje pravosudnih funkcija država ili u organizaciju njihovih sudskih sustava. Odgovornost za dosljednost njihovih odluka je na nacionalnim sudovima, a djelovanje ESLJP-a trebala bi ostati iznimka. Smatra da okolnosti ne iziskuju takvo djelovanje i da njegova uloga nije tražiti rješenje za osporenu proturječnost sudske prakse u odnosu na članku 6. Individualni se zahtjev ne može koristiti kao sredstvo za razmatranje ili uklanjanje proturječnosti sudske prakse, koja se može pojaviti u domaćem pravu, ili kao mehanizam za preispitivanje čiji je cilj usklađivanje nedosljednosti u odlukama različitih nacionalnih sudova. Stoga nije došlo do povrede članka 6 .

U predmetu Vusić protiv Hrvatske podnositelj je podnio Općinskom sudu tužbu radi predaje u posjed kuće, tvrdeći da mu je ta kuća bila darovana. U tužbi je kao vrijednost spora naveo 1.000 .000 nekadašnjih jugoslavenskih dinara. U podnesku sudu od 1. ožujka 2001. podnositelj je zahtjeva naveo da je vrijednost spora 101.000 hrvatskih kuna. Općinski sud presudio je na štetu podnositelja zahtjeva. Županijski je sud odbio žalbu podnositelja zahtjeva i potvrdio prvostupanjsku presudu. Podnositelj zahtjeva izjavio je reviziju protiv drugostupanjske presude. Općinski sud odbacio je njegovu reviziju ratione valoris, jer je smatrao da je vrijednost predmeta spora ispod zakonom utvrđenog cenzusa od 100.000,00 kuna. Utvrdio je da je vrijednost predmeta spora bila 1.000.000 dinara što iznosi 1 kunu. Podnositelj se zahtjeva žalio protiv tog rješenja. Sud je utvrdio da je mjerodavna ona vrijednost predmeta spora koju

22 Unédic protiv Francuske, presuda, 18. prosinca 2008., br. 20153/04.

23 Vidi, Atanasovski protiv „Bivše Jugoslovenske Republike Makedonije”, presuda, 14. siječnja 2010., br. 36815/03. 
je tužitelj naznačio u tužbi te da naknadne promjene nisu bile mjerodavne. Uz to je ispravio izračun prvostupanjskog suda utvrdivši da je vrijednost predmeta spora što ju je podnositelj zahtjeva naveo u tužbi zapravo iznosi samo 0,10 lipa. Podnositelj je zahtjeva Vrhovnome sudu izjavio reviziju protiv tog rješenja. Vrhovni je sud zaključio da je mjerodavna ona vrijednost predmeta spora koju je tužitelj naznačio u tužbi, a da je u ovome predmetu to vrijednost od 1.000.000 dinara što, kad se preračuna u kune, iznosi 0,10 kuna. Podnositelj je podnio ustavnu tužbu navodeći da mu je povrijeđeno ustavno pravo na pošteno suđenje. Ustavni je sud presudio da je sporno rješenje u skladu s mjerodavnim odredbama Zakona o parničnom postupku te da mu u postupku pred redovnim sudovima nije povrijeđeno ustavno pravo na pošteno suđenje.

U postupku pred ESLJP-om podnositelj se žalio na povredu članka 6. Ponavlja da članak 6. ne prisiljava države ugovornice na osnivanje žalbenih ili kasacijskih sudova. Međutim, kad takvi sudovi postoje, jamstva članka 6. moraju se poštovati, na primjer u smislu da on jamči parničnim strankama djelotvorno pravo na pristup sudovima radi donošenja odluke o njihovim građanskim pravima i obvezama. ESLJP primjećuje da su izmjene i dopune Zakona o parničnom postupku iz 1999., kojima je zakonom utvrđeni cenzus za izjavljivanje revizije podignut na 100.000 kuna bile primjenjive na njegov predmet. One su u skladu s općepriznatim načelom da se postupovna pravila trenutačno primjenjuju na postupke koji su u tijeku. ${ }^{24}$ Povodom revizije Vrhovni je sud ukinuo odluke nižih sudova i vratio predmet prvostupanjskom sudu na ponovno odlučivanje. Kad je prvostupanjski sud Vrhovnome sudu dostavio spis predmeta i podnositeljevu reviziju Vrhovni je sud, reviziju proglasio nedopuštenom ratione valoris bez ikakva obrazloženja o tome zašto je odstupio od svoje prethodne odluke. ESLJP je utvrdio kako u okolnostima u kojima ni Vrhovni sud ni Ustavni sud uopće nisu spomenuli prethodno rješenje koje se odnosilo na isto pitanje $u$ istome predmetu niti su dali iscrpno obrazloženje, ne može znati zašto su ta dva rješenja različita. ESLJP ponavlja da je jedno od temeljnih vidova vladavine prava načelo pravne sigurnosti, načelo koje je implicitno sadržano u Konvenciji. Ako nema mehanizma koji osigurava dosljednost, proturječne odluke u sličnim predmetima koje je donio isti sud, koji je uz to zadnja instanca u spomenutoj pravnoj stvari, mogu dovesti do povrede tog načela i time potkopati povjerenje javnosti u pravosuđe. To je povjerenje jedna od bitnih sastavnica države utemeljene na vladavini prava. Države ugovornice su obvezne organizirati svoje pravne sustave tako da se izbjegne donošenje proturječnih presuda. ESLJP smatra da se takvo mišljenje a fortiori primjenjuje u ovome slučaju u kojemu je isti sud $u$ istome predmetu donio proturječne odluke. Kako je već utvrdio povredu članka 6. u sličnim okolnostima smatra da dvije proturječne odluke Vrhovnoga suda $\mathrm{u}$ istome predmetu nisu u skladu s načelom pravne sigurnosti. Uloga višega suda $u$ ugovornoj stranci upravo je rješavati sukobe u sudskoj praksi, izbjegavati razilaženja i osigurati jedinstvenu primjenu zakona. Stoga je donošenjem novog rješenja o istome pitanju u istome postupku, suprotnom od prethodnog rješenja, Vrhovni sud u tom predmetu sam postao izvor nesigurnosti. Time je povrijedio načelo pravne sigurnosti sadržano u članku 6.

24 Brualla Gómez de la Torre protiv Śpanjolske, presuda, 19. prosinca 1997., br. 26737/95. 


\section{PRIMJENA USTAVNO KONVENCIJSKIH NAČELA PRAVNE SIGURNOSTI NA NACIONALNOJ NORMATIVNOJ RAZINI}

\subsection{Unutarnja organizacija sudova i ujednačavanje sudske prakse}

U cilju usklađivanja judikature sukladno s odredbama Zakona o sudovima ${ }^{25}$ (zadnje izmjene stupile na snagu 1. siječnja 2019.) određeno je više različitih pravila u cilju omogućavanja usklađivanja sudske prakse.

Ponajprije je istaknuto da je viši sud dužan nižem sudu ukazati na nedostatke koje je uočio pri odlučivanju o pravnom lijeku ili drukčije. To znači da će u svojim odlukama u povodu pravnih lijekova viši sudovi dati konkretne upute sudu prvog stupnja o tom postupku, ali i o primjeni materijalnog prava. Takvo mišljenje suda drugog stupnja djeluje samo u konkretnom postupku, ali nije bez utjecaja i na druge slične predmete. Naime snagom pravnih argumenata iz pojedinačne odluke može se pozitivno djelovati na ujednačenu primjenu pojedinih pravnih instituta. No, viši sud ne smije nikako utjecati na neovisnost i slobodu suda nižeg stupnja u donošenju odluke u pojedinom predmetu. Ipak, kada je viši sud ukinuo konkretnu odluku suda prvog stupnja, onda je prvostupanjski sud dužan izvesti sve parnične radnje i raspraviti sva sporna pitanja na koja je upozorio drugostupanjski sud u svom rješenju. ${ }^{26}$ Dakle, prvostupanjski je sud konkretno obvezan izvesti sve parnične radnje i raspraviti sva sporna pitanja, ali prvostupanjski sud ima i dalje slobodu u donošenju odluke, ako snaga pravnih argumenata nije bila dostatna.

Nadalje, viši sud može tražiti od nižeg suda podatke u svezi s primjenom zakona, problemima koji se javljaju u suđenju, praćenju i proučavanju sudske prakse te druge podatke, a može provesti i neposredni nadzor nad radom tog suda i pojedinih sudaca, kao i organizirati zajedničke sastanke radi razmatranja navedenih pitanja.

Dakle, osim kroz pojedinačne odluke, viši sud do saznanja o praksi suda nižeg stupnja dolazi i kroz pravilo kojim predsjednik neposredno višeg suda treba u pravilu odrediti jednom godišnje provođenje nadzora nad urednim obavljanjem poslova sudaca i sudova na području svoje nadležnosti. Taj nadzor obavljaju suci neposredno višeg suda koje je odredio predsjednik toga suda (čl. 28. st. 1. ZoS). Tijekom vršenja nadzora pregledavaju se i konkretni predmeti na kojima radi sud prvog stupnja te suci koji vrše nadzor sastavljaju i pisano izvješće koje se dostavlja predsjedniku suda koji je odredio nadzor, a on dostavlja predsjedniku nadziranog suda, predsjedniku Vrhovnog suda, Državnom sudbenom vijeću i Ministarstvu pravosuđa. Iako je ponajprije cilj nadzora utvrditi urednost obavljanja poslova, u sklopu toga sud višeg stupnja dolazi do informacija i o novim pravnim problemima koji su se pojavili pred sudovima nižeg stupnja.

Osim kroz nadzor, predsjednik suda višeg stupnja može zatražiti podatke od

25 Zakon o sudovima, Narodne novine, br. 28/13., 33/15., 82/15., 82/16., 67/18. (dalje u tekstu: $\mathrm{ZoS})$.

26 Čl. 377. st. 2. Zakona o parničnom postupku, Narodne novine, br. 53/91., 91/92., 58/93., 112/99., 88/01., 117/03., 88/05., 02/07., 84/08., 96/08., 123/08., 57/11., 148/11., 25/13., 89/14., 70/19. (dalje u tekstu: ZPP). 
suda nižeg stupnja u svezi s primjenom zakona koji su se pojavili u praksi te se o tim problemima mogu organizirati i rasprave na sudu višeg stupnja i zajednički sastanak radi razmatranja navedenih pitanja. Rasprave o navedenim pitanjima ne smiju nikako utjecati na neovisnost i slobodu suda nižeg stupnja u donošenju odluke u pojedinom predmetu, iako utječu na ujednačavanje pravne praske snagom svojih argumenata.

Štoviše, Vrhovni sud će radi razmatranja spornih pravnih pitanja koja se odnose na drugostupanjsko sudovanje, u svrhu ujednačavanja sudske prakse, svakih šest mjeseci, a po potrebi i češće, organizirati zajednički sastanak s predsjednicima sudskih odjela svih županijskih sudova. Zaključci sa sastanaka objavit će se na mrežnoj stranici Vrhovnog suda (čl. 27. ZoS.). ${ }^{27} \mathrm{Na}$ predmetnim se sastancima razmatraju pravna pitanja za koja je uočeno da drugostupanjski sudovi nemaju jedinstveno stajalište te se objavljuju kako bi ih znale stranke i svi suci. Tako je, npr. na sastanku predsjednika građanskih odjela županijskih sudova i Građanskog odjela Vrhovnog suda održanom 27. studenog 2019. zauzeti i pravni stav da zastarni rok za naplatu potraživanja $s$ osnova pruženih usluga isporuke radiotelevizijskih programa ili sličnih programa putem DTH tehnologije iznosi tri godine. Prethodno navedeni zaključci i mišljenja sudaca viših sudova utječu pozitivno na ujednačavanje pravne prakse, ali njihova primjena nije obvezatna ni za suce toga suda ni za suce nižih sudova jer ponajprije sudjeluju samo predsjednici odjela nižih sudova, a ne svi suci toga suda. No, ipak snaga pravnih argumenata nije mala, te ovi javno objavljeni zaključci pozitivno utječu na ujednačavanje pravne prakse. Pored toga, za donošenje zaključaka i mišljenja nije nužno da su prethodno na sudovima već donesene različite odluke, već je moguće određeno pravno pitanje raspraviti i prije donošenja pojedinačnih odluka.

Drukčija je situacija ako se zauzima obvezno pravno shvaćanja. Naime, da bi se sazvala sjednica odjela ili sudaca sa zahtjevom za zauzimanje obveznog pravnog shvaćanja prethodno se mora utvrditi da o pitanjima primjene zakona postoje razlike u shvaćanjima između pojedinih odjela, vijeća ili sudaca ili kad u jednom odjelu vijeće ili sudac odstupi od ranije prihvaćenog pravnog shvaćanja (čl. 40. ZoS). Ako se na sjednici svih sudaca odnosno sudskog odjela Vrhovnog suda, ali i Visokog trgovačkog suda, Visokog upravnog suda, Visokog prekršajnog suda i sjednici odjela županijskog suda zauzme pravno shvaćanje o spornom pravnom pitanju, ${ }^{28}$ onda to mišljenje obvezuje sva drugostupanjska vijeća ili suce pojedince tog odjela, odnosno suda (čl. 40. st. 2.). Ta pravna shvaćanja nije obvezno objaviti na mrežnim stranicama suda, no većina ih sudova objavljuje. ${ }^{29}$ Tako je, primjerice, na sjednici građanskog odjela Vrhovnog suda održanoj 18. travnja 2019. zauzeto shvaćanje: „Korištenje nevjerodostojne svjedodžbe prilikom zasnivanja radnog odnosa opravdan je razlog za redoviti otkaz ugovora o radu zbog skrivljenog ponašanja, neovisno što na temelju te

27 Zaključci su objavljeni na mrežnoj stranici: http://www.vsrh.hr/EasyWeb.asp?pcpid=2152, pristup 13. studeni 2019.

28 Sjednice odjela zauzimaju pravno shvaćanje većinom glasova svih sudaca.

29 Pravna shvaćanja građanskog odjela Vrhovnog suda objavljena su na mrežnoj stranici: http:// www.vsrh.hr/EasyWeb.asp?pcpid=2150 a kaznenog odjela: http://www.vsrh.hr/EasyWeb. asp?pcpid=2151. Pravna shvaćanja Visokog trgovačkog suda objavljena su na mrežnoj stranici: https://www.vtsrh.hr/ index.php?page=development\&article_id=4423\&lang=hr, pristup 13. studeni 2019. 
svjedodžbe nije sklopljen ugovor o radu niti je za poslove koje je radnik obavljao kod poslodavca bila potrebna stručna sprema iz nevjerodostojne svjedodžbe pa okolnost da je poslodavac radniku dao redoviti otkaz koji je za njega povoljniji, a ne izvanredni otkaz, ne utječe na zakonitost odluke o redovitom otkazu ugovora o radu“. Kako je riječ o postupku koji se odnosi na raskid ugovora o radu, te je u ovoj vrsti postupka uvijek dopuštena redovna revizija (čl. 382.a ZPP-a), predmetno pravno shvaćanje neće samo utjecati na građanski odjel Vrhovnog suda, nego i na same stranke i sve sudove nižeg stupnja. Naime, kada stranka zna stav najvišeg suda, onda će sigurno u slučaju drukčije odluke sudova nižeg stupnja izjavljivati pravne lijekove te će u konačnici o tom pitanju odlučivati sud koji je i vezan sa svojim pravnim shvaćanjem. Iako se obvezatnost spomenutih pravnih shvaćanja proteže isključivo na drugostupanjska vijeća odnosno suce odjela viših sudova, odnosno viših sudova kao cjeline, a ne i na prvostupanjske sudove. No, praktičan su problem situacije kada viši sudovi ne uspiju zauzeti pravno stajalište jer su mišljenja oko određenoga pravnog pitanja toliko podijeljena pa niti jedno ne uspije dobiti potporu više od polovice sudaca toga suda. Međutim, nužnost usuglašavanja sudske prakse, istoga postupanja u istim stvarima, pravne sigurnosti i predvidivosti pravnog poretka, prema sve prisutnijim stajalištima domaćih i međunarodnih stručnjaka, ne smije ugroziti neovisnost suca koji postupa u određenom predmetu. Dakle, ni jedan od propisanih instrumenata ujednačavanja sudske prakse ne obvezuje prvostupanjske sudove na odlučivanje koje bi bilo apsolutno usklađeno s načelnim stajalištima viših sudova, niti za tu tvrdnju postoji racionalna potreba. ${ }^{30}$

\subsection{Organizacija sudova i ujednačavanje sudske prakse}

Razlike u sudskoj praksi posljedice su svojstvene svakom sudskom sustavu koji je utemeljen na mreži postupajućih i žalbenih sudova s ingerencijama na području svoje teritorijalne nadležnosti. Stoga, u traženju i drugih modaliteta za problem neujednačene sudske prakse krenulo se još jednim smjerom, umetanjem novog Zakona o područjima i sjedištima sudova ${ }^{31}$ (stupio na snagu 1. siječnja 2019.), jer je smatrano kako je dotadašnja organizacija mreže općinskih sudova neodgovarajuća i neučinkovita u pružanju zaštite građanima i gospodarstvu. Primjerice, u postupku žalbe protiv odluka općinskih sudova i dodjeljivanja predmeta različitim županijskim sudovima nasumičnom algoritamskom dodjelom još više je došla do izražaja neujednačenost prakse hrvatskih sudova. No, iako je donošenje zakona važan korak, tek je njegov život u praksi, odnosno primjena na hrvatskim sudovima, pravi pokazatelj njegove važnosti i učinka. Za sada se uočava da je takva dodjela predmeta dovela do bržega rješavanja predmeta pred drugostupanjskim sudovima jer su neki sudovi ranije bili iznimno opterećeni. No, sada su određena pravna pitanja prisutna na svim drugostupanjskim sudovima, iako se ona javljaju samo u određenom području (primjerice, pitanje optantske imovine koje je specifično za područje Istre, sada rješavaju županijski sudovi u cijeloj državi). Takva dodjela predmeta zahtijeva dodatno

30 Alen Rajko, „Odnos predsjednika suda sa sudskim strankama - pravno uređenje i pitanja iz prakse", Zbornik Pravnog fakulteta Sveučilišta u Rijeci 40, br. 1 (2019): 573-587.

31 Zakon o područjima i sjedištima sudova, Narodne novine, br. 67/18. 
obrazlaganje činjenica koje se smatraju općepoznatima na određenom području, ali ne i na području cijele države (npr. pitanja pravnih slijednika komunalnih društava). I dalje su najveći problem za stranke slučajevi u kojima različiti drugostupanjski sudovi donose potpuno različite odluke $u$ istom pravnom pitanju. ${ }^{32}$ Takvo razilaženje u stajalištima nastoji se riješiti zauzimanjem zajedničkih zaključaka na zajedničkim sastancima sudaca Vrhovnog suda sa s predsjednicima sudskih odjela svih županijskih sudova.

\subsection{Zakon o parničnom postupku i ujednačavanje sudske prakse ${ }^{33}$}

Na predmetni se problem nastojalo odgovoriti uvođenjem u parnični postupak instituta izvanredne revizije koji je trebao omogućiti da Vrhovni sud ${ }^{34}$ ostvari svoju ustavnu i zakonsku funkciju osiguravanjem jedinstvene primjene zakona i onda kad nije bilo uvjeta za izjavljivanje redovite revizije. ${ }^{35}$ Pritom je zakonodavac odredio kako je sud kome je predmet vraćen na ponovno suđenje vezan u tom predmetu pravnim shvaćanjem na kojemu se temelji rješenje revizijskoga suda kojim je ukinuta pobijana drugostupanjska, odnosno kojim su ukinute drugostupanjska i prvostupanjska presuda (čl. 394.a ZPP). Ipak posljednje godine obilježile su sve izraženije i oštrije javne rasprave i neslaganja oko odgovarajuće uloge Vrhovnog suda. Stoga Nacrt prijedloga Zakona o izmjenama i dopunama Zakona o parničnom postupku upućen u javnu raspravu sredinom 2016., a kasnije i novela Zakona o parničnom postupku iz 2019. donosi brojne novine. Jedna od većih, ako ne i najveća, svakako se odnosi

32 Tako je uočena između ostalog i različita praksa viših sudova koja se odnosi na stečaj potrošača i to pokretanje toga postupka i plan ispunjenja obveza - primjena čl. 44., st. 3. i 4. i čl. 17., st. 1. Zakona o stečaju potrošača. Sporan je slučaj kada je plan ispunjenja obveza potrošača podnesen na propisanom obrascu, no ne sadrži postotak umanjenja obveza potrošača, iznose za isplatu, rokove isplate i način ispunjenja, već se predlaže otpis svih obveza u $100 \%$-tnom iznosu. Stoga se postavilo pitanje može li i treba li u tom slučaju sud odbaciti prijedlog za otvaranje postupka stečaja potrošača ili to ne može biti razlog za odbačaj prijedloga. Županijski sud u Osijeku u rješenju br. Gž-811/18 od 13. rujna 2018. zauzeo je stajalište da to ne može biti razlog za odbacivanje prijedloga, dok Županijski sud u Vukovaru u rješenju br. Gž-465/18 od 22. kolovoza 2018. smatra da u tom slučaju treba prijedlog, odbaciti stoga što takav plan u svojoj biti nije plan ispunjenja obveza, već zahtjev za otpis, odnosno oprost dugova jer u njemu nema podataka da bi potrošač predložio umanjenje neke obveze, rokove isplate i način ispunjenja.

33 Navedena je problematika analizirana i u radu, Dejan Bodul, „O problemima ujednačavanja sudske prakse prema Noveli Zakona o parničnom postupku iz 2019.”, Novi Informator br. 6592 (2019.): 12-13.

34 VSRH je do 2008. odlučivao i o pravnom sredstvu za ujednačavanje tumačenja i primjene prava - o zahtjevu za jedinstvenom primjenom prava. Ovo izvanredno pravno sredstvo utvrđivao je tada čl. 59. Zakona o sudovima te je državnom odvjetniku i stranci davao pravo da se kada god sudovi drugog stupnja donose različite odluke u istoj činjeničnoj i pravnoj stvari, ovim zahtjevom obrate Vrhovnom sudu, a da nije dopušten izvanredni pravni lijek, ovim zahtjevom obrate Vrhovnom sudu.

35 Za poredbena rješenja, Božidar Vujičić, „Ujednačavanje sudske prakse u građansko pravnoj materiji - problemi i moguća rješenja", Bilten Vrhovnog Kasacijskog suda, br. 3 (2012.): 263-276; Nina Betetto, "Uloga slovenskoga Vrhovnog suda u ujednačavanju sudske prakse", Zbornik Pravnog fakulteta u Zagrebu 68, br. 5-6 (2018.): 685-705. 
i na postupak u povodu revizije kao izvanrednoga pravnog lijeka. Naime, empirija ukazuje kako je VSRH preopterećen i to najvećim dijelom zbog preširoko definirane mogućnosti pristupa VSRH-u preko instituta revizije, čime je dovedeno u pitanje i učinkovito ostvarivanje njegove ustavne uloge. Stoga je i izmijenjen ,revizijski dio" Zakona. Tendencija je u promjeni paradigme revizije prema kojoj je njena javna funkcija jedino prihvatljiva, jer bez nje nema rješenja preopterećenosti Vrhovnog suda. U načelu, postavljanje konkretnih pragova vrijednosti (kriterij dopuštenosti ratione valoris) za pristup vrhovnom sudu ESLJP smatra kako se slijedi legitiman cilj, kojim se osigurava da se sud bavi samo bitnim stvarima koji priliči njegovoj ulozi. ${ }^{36}$

\subsubsection{Novi model revizije i rasprave koje su prethodile}

Rasprava o novom uređenju revizije u parničnom postupku rasprava je o ulozi Vrhovnog suda u zaštiti konkretnih prava stranaka i osiguranju jedinstvene primjene prava i ravnopravnosti svih u njegovoj primjeni. Još u raspravi u povodu Nacrta iskristalizirala su se dva stajališta: zadržati supostojanje redovne i izvanredne revizije te, drugo, kreirati isključivo reviziju po dopuštenju Vrhovnog suda.

Prvo stajalište odnosno za koegzistenciju redovne i izvanredne revizije osobito se zalaže Hrvatska odvjetnička komora (dalje u tekstu: HOK). Naime, oni navode kako u trendu smanjenja procesnih prava stranaka, dosadašnjim novelama ZPP-a preuređen je prvostupanjski postupak podjelom na stadij prethodnog postupka i glavne rasprave i uvođenjem novih procesnih prekluzija. $U$ drugostupanjskom postupku sud je dobio bitno proširene reformacijske ovlasti koje nisu popraćene adekvatnim razmjernim procesnim pravima stranaka u drugostupanjskom postupku u slučaju preinačenja prvostupanjskih odluka. ${ }^{37}$ Štoviše, HOK izražava zabrinutost jer se u predloženom nacrtu izmjena i dopuna ZPP-a u odnosu na reviziju u pravni sustav unose: pravna nesigurnost i neizvjesnost (što je suprotno čl. 3., 5. i 29. Ustava RH) - mogućnost, kako kaže Ustavni sud RH, sudske arbitrarnosti, samovolje i nedopuštene diskrecije, to jest ni od koga kontrolirane diskrecijske ovlasti sudova, što dovodi u pitanje jednakost $\mathrm{i}$ vladavinu prava, kao najviše ustavne vrednote (čl. 3. Ustava), kao i ustavna načela jednakosti svih pred zakonom i sudovima (čl. 14. st. 2. i čl. 26. Ustava) - nejasni i arbitrarni kriteriji prema kojima se o(ne)mogućava pristup Vrhovnom sudu. ${ }^{38}$ Dika navodi da država, koja pretendira biti pravna, socijalna i demokratska (arg. ex 1., 3., 5., 14., 16., 18., 29., 119. Ustav RH), mora osigurati proceduralne instrumente za osiguranje jedinstvene primjene prava i ravnopravnosti svih u njegovoj primjeni u javnom, općem interesu, ali i u privatnom, partikularnom interesu. ${ }^{39}$ Zamjenik Glavnog državnog odvjetnika Koketi ističe kako način i instrument uređenja revizije kako je u prijedlogu Zakona napisan ima za posljedicu ono što smo već u pravnom

36 Zubac protiv Hrvatske, presuda, 5. travnja 2018., br. 40160/12.

37 Antun Šagovac, „Stranputice revizije prema Nacrtu prijedloga Zakona o izmjenama i dopunama Zakona o parničnom postupku", Novi informator br. 6565 (2019): 2-3.

38 Šagovac, „Stranputice revizije prema Nacrtu prijedloga Zakona o izmjenama i dopunama Zakona o parničnom postupku": 2-3.

39 Mihajlo Dika, „Marginalije uz prijedlog novog uređenja revizije u parničnom postupku (2018.)", Odvjetnik, br. 3-4 (2018): 25. 
sustavu imali te da je to rezultiralo znatnim povećanjem predmeta na drugom mjestu, na Ustavnom sudu RH. Dodatno je da će državu takav instrument uređenja revizije bitno više koštati od postojećeg sustava. Naime, o nekom će se predmetu dva puta raspravljati pred istim sudom. Navodi kako će to pasti na leđa svih poreznih obveznika, te u našem zakonodavstvu i procesu izmjene svih zakona u pravilu možete pročitati samo jednu rečenicu, između ostalog, u primjeni ovoga zakona neće trebati dostatna sredstva i neće se ništa izdvojiti. ${ }^{40}$ U kritici mu se priklanja i Nakić, umirovljeni zamjenik državnog odvjetnika u Rijeci, navodeći kako je osnovni problem činjenica da revidenti nisu mogli doći do saznanja o odlukama nižih i viših sudova. Naime, nema zakonske obveze navedenih sudova da svu (treba izuzeti obiteljsko pravne sporove) sudsku praksu objavljuju na mrežnim stranicama, odnosno da je na drugi način učine dostupnom. Iz Nacrta Zakona proizlazi da revident mora imati saznanja o svim odlukama sudova RH iz kojih proizlazi nejedinstvenost u primjeni prava. To pretpostavlja da bi strankama na upotrebi trebale biti javne, dostupne i pregledne baze podataka sudske prakse, no takvih baza podataka u ovom trenutku u RH nema. ${ }^{41}$ Također je mišljenja kako bi ponovno trebalo, po uzoru na slovensko rješenje koje je poslužilo kao transplatativni uzor za model nove revizije, implementirati institut zahtjeva za zaštitu zakonitosti koji može biti sredstvo ujednačavanja sudske prakse.

Za reviziju po dopuštenju zalažu se, u većem dijelu, suci Vrhovnog suda, uz obrazloženje da Vrhovni sud, prema de lege lata uređenju dvostrukog kolosijeka, ne može ostvariti ustavnu ulogu revizijskog suda zbog velikih zaostataka odnosno neriješenih revizijskih predmeta. ${ }^{42}$ Katić navodi da je revizija iz Nacrta dijelom utemeljena na modelu iz postupovnog uređenja naših susjeda u Sloveniji, Njemačkoj te Austriji, ali je u biti novi model revizije radi omogućavanja da se najviši sud $u$ državi bavi, ponajprije javnopravnim interesom i tako učinkovito ostvaruje svoju ustavnu ulogu ujednačavajući i razvijajući sudsku praksu. Nadalje navodi kako je svjesno bio ,žrtvovan" pojedinačni privatni interes naspram javnopravnog. ${ }^{43} \mathrm{Na}$ istom je stajalištu i sudac Vrhovnog suda Kontrec koji navodi kako je postojeći koncept revizije neodrživ. ${ }^{44}$ Garašić se načelno zalaže za novi model, reviziju po dopuštenju, ali usporedno predlaže da se zadrži, barem privremeno, i dosadašnje uređenje, tzv. redovne revizije, $i$ to iz niza razloga. ${ }^{45}$ I Bratković zastupa mišljenje da revizija po

40 Jakša Barbić i Marko Bratković, ur., Godišnjak Tribina Pravnog fakulteta Sveučilišta u Zagrebu i Kluba Pravnika grada Zagreba (2017): 25.

41 Jakob Nakić, „(Izvanredna) revizija po Zakonu o parničnom postupku na razmeđi?”, u: Aktualnosti hrvatskog zakonodavstva i pravne prakse, tradicionalno XXXIII. Savjetovanje, Hrvatsko društvo za građansko pravne znanosti i praksu, Godišnjak 25 (Zagreb: Organizator, 2018.), 263. et seq.

42 Dragan Katić, „O revizijama i noveliranju Zakona o parničnom postupku”, Odvjetnik br. 3-4 (2018.): 61-64.

43 Barbić i Bratković, ur., Godišnjak Tribina Pravnog fakulteta Sveučilišta u Zagrebu i Kluba Pravnika grada Zagreba, 19.

44 Barbić i Bratković, ur., Godišnjak Tribina Pravnog fakulteta Sveučilišta u Zagrebu i Kluba Pravnika grada Zagreba, 21.

45 Jasnica Garašić, „Osvrt na novopredložene odredbe o reviziji u parničnom postupku u 18. nacrtu prijedloga Zakona o izmjenama i dopunama Zakona o parničnom postupku", Odvjetnik br. 3-4 (2018.): 56-58. 
dopuštenju pro futuro u hrvatskom građanskom postupovnom pravu treba biti i jedina revizija navodeći kako postojećim normativnim uređenjem predviđena svrha revizije u hrvatskoj parničnoj praksi nije ostvarena jer Vrhovni sud, odlučujući u tako veliku broju predmeta, ne može ostvarivati svoju ustavnu zadaću osiguranja jedinstvene primjene prava i ravnopravnosti svih u njegovoj primjeni (javna funkcija), niti ispuniti očekivanja individualnih stranaka da brzo i kvalitetno odluči o zakonitosti odluke protiv koje su podnijeli reviziju (privatna funkcija) ${ }^{46} \mathrm{Na}$ istom je tragu i Uzelac, idejni tvorac navedenoga modela revizije, koji smatra da je teško zamisliti da situacija može biti gora od postojeće. ${ }^{47}$

Na temelju Novele ZPP-a iz 2019., kao rezultat svojevrsnoga kompromisa, dvije su vrste revizije. Prva je, tzv. revizija po dopuštenju, sasvim novi oblik revizije koji hrvatski pravni poredak u trgovačkim i građanskim stvarima nije poznavao. Bit je revizije po dopuštenju da stranke u sporu mogu podnijeti reviziju protiv presude donesene u drugom stupnju, ako je Vrhovni sud RH dopustio njezino podnošenje (čll. 382. ZPP-a). Iako je postojala tendencija da se uvede isključivo revizija po dopuštenju, to se na kraju nije ostvarilo.

Iznimno, stranke mogu podnijeti reviziju protiv presude u drugom stupnju, bez dopuštenja Vrhovnog suda RH, ali samo u taksativno propisanim sporovima (čl. 382.a ZPP-a). Dakle, takva druga vrsta revizije, redovna revizija, tj. revizija bez dopuštenja izrijekom je utvrđena kao iznimka.

\subsection{2. „Skokovita revizija“ i pitanja za razmatranje}

Više od 20 godina u sudskoj praksi su predmeti kojih ima i više stotina (pa i tisuća), a u osnovi je sporno jedno pravno pitanje. Tako je, exempli gratia, bilo i u predmetima, tzv. viška kvadrata (otkup vojnih stanova, nakon što je Ustavni sud RH utvrdio ništetnim odredbu posebnog zakona koja je određivala drukčiju cijenu od otkupne cijene za druge stanove), gdje su sudovi zauzimali različita pravna shvaćanja o pravu na povrat pretplaćenog iznosa, a vođeno je nekoliko tisuća parničnih postupaka. Stoga je zakonodavac novelom ZPP-a iz 2019. nakon članka 502.h dodao glavu trideset drugu - b, Ogledni postupak radi rješenja pitanja važnog za jedinstvenu primjenu prava i članaka 502.i, 502.j, 502.k. Time je omogućio Vrhovnom sudu RH da u ranoj etapi postupka, praktično odmah nakon podnošenja tužbe, zauzme određeno pravno stajalište osiguravajući jedinstvenu primjenu prava u cijeloj državi. Ogledna je parnica time u bitnome izjednačena s novom revizijom. Iako su prvotne ideje o primjeni ovog instituta u parnični postupak polazile od ideje oglednog spora iz Zakona o upravnim sporovima ${ }^{48}$ taj je koncept napušten i zamijenjen institutom

46 Marko Bratković, Revizija po dopuštenju 2018., doktorska disertacija (Zagreb: Pravni fakultet, 2018.); Marko Bratković, „Što je važno pravno pitanje u reviziji?”, Zbornik Pravnog fakulteta u Zagrebu 68, br. 5-6 (2018.): 853-880; Marko Bratković, „Reforma revizije u parničnom postupku", Hrvatska pravna revija 17, br. 2 (2017.): 79-94.

47 Barbić i Bratković, ur., Godišnjak Tribina Pravnog fakulteta Sveučilišta u Zagrebu i Kluba Pravnika grada Zagreba, 24.

48 Čl. 48. Zakona o upravnim sporovima, Narodne novine, br. 20/10., 143/12., 152/14., 94/16., 29/17. 
koji je po svojim značajkama mnogo bliži postupku rješavanju spornih pitanja pravno tradicijski sličnih sustava, primjerice, Srbije (prije čl. 176.-180., a sada čl. 180.-185. ZPP-a ${ }^{49}$ ) te Federacije Bosne i Hercegovine (poglavlje III.a, čl. 61.a -61.f). ${ }^{50,51}$

Ogledni postupak pokreće sud prvog stupnja ako je pokrenut parnični postupak. Po ZPP-u to su postupci u kojima odluka ovisi o rješavanju istog pravnog pitanja, slični sporovi, koji su: u većem broju već pokrenuti ili se njihovo pokretanje očekuje u kraćem razdoblju; rješenje koje ovisi o istom pravnom pitanju; pravno pitanje važno za osiguravanje jedinstvene primjene prava i ravnopravnosti svih u njegovoj primjeni ili za razvoj prava kroz sudsku praksu. U svezi s izloženom definicijom doktrina je već naznačila da nije odgovoreno što znači „u većem broju“ te što su „slični sporovi“, jesu li to sporovi s istovrsnom činjeničnom i pravnom osnovom (i između istovrsnih pravnih subjekata) u kojima bi bili istaknuti bitno istovrsni zahtjevi ili bi se sličnost trebala prosuđivati (i) prema nekim drugim kriterijima. Međutim, izgleda da za navedene situacije ipak nema jedinstvenoga procesnog pravila jer odgovor na postavljeno pitanje ovisi o svim okolnostima konkretnoga slučaja i različit je u svakom pojedinačnom predmetu. Nadalje, zakonodavac se u tom slučaju odlučio da odluku u oglednom postupku donosi vijeće pet sudaca Vrhovnog suda, vjerojatno uvažavajući i činjenicu velikog broja predmeta koji su sada u tijeku pred tim sudom. ${ }^{52}$ No, radi zauzimanja pravnoga shvaćanja u tako bitnim predmetima, bilo bi dobro da se ipak odlučuje u vijeću većeg broja sudaca ili da se prije odluke vijeća održi sjednica odjela na kojoj bi se raspravljalo o predmetnom pravnom pitanju. ${ }^{53}$ Kao sporan pokazuje se prijelazni režim koji određuje da će se odredbe navedene glave primjenjivati i na sve postupke u kojima do 1. rujna 2019. nije održano pripremno ročište ili je održano pripremno ročište, ali nije zaključen prethodni postupak. Tako se primjenjuju i pravila o prekidu parničnih postupaka, dok je za pravila iz članaka 213.a i 215. ZPP-a određeno da će se primjenjivati samo na postupke koji su pokrenuti nakon stupanja na snagu Novele, tj. od 1. rujna 2019. U odnosu na ovaj institut nema sustavne analize njegove učinkovitosti, a posljedice uvođenja instituta u parnične postupke nekih susjednih

49 Službeni glasnik RS, br. 72/11., 49/13. - odluka US, 74/13 - odluka US, 55/14. i 87/18.

50 Zakon o parničnom postupku Federacije Bosne i Hercegovine, Službene novine Federacije BiH, br. 53/03., 73/05., 19/06. te 98/15.

51 Ovo bi trebalo razgraničiti od prethodnoga pitanja iz čl. 12. ZPP-a. Prethodno pitanje, kao nerazriješeno uvjetujuće pitanje, naime, prema općem stajalištu civilnog procesa ne rješava samo Vrhovni sud, već i postupajući prvostupanjski sud u pravnim stvarima koje su u tijeku. O zauzetom stajalištu prvostupanjskog suda o pravnom pitanju, može se izjasniti i Vrhovni sud, ali redom, tek nakon što je prvo i drugostupanjski postupak okončan. Ovaj postupak treba razgraničiti od postupka prethodnog odlučivanja pred Sudom Europske unije koji je ovlašten da o određenim pitanjima odluči s prejudicijalnim učinkom. Postupak za rješavanje prethodnog pitanja posebna je vrsta postupka pred tim europskim sudom, nije riječ o klasičnom građanskopravnom sporu, to je postupak sui generis za pružanje pravne pomoći nacionalnim sudovima.

52 Pred Vrhovnim je sudom 31. prosinca 2018. bilo 14.219 neriješenih predmeta u građanskom odjelu, pristup 6. rujna, 2019., http://www.vsrh.hr/EasyWeb.asp?pcpid=28.

53 U predmetima, tzv. „višak kvadrata” vijeće Vrhovnog suda potvrđivalo je odluke kojima je odbijen tužbeni zahtjev (u to vrijeme su pravila o reviziji omogućavala da takvi predmeti dospiju do Vrhovnog suda RH), no takve je odluke ukinuo Ustavni sud, stoga je promijenjeno pravno shvaćanje na Vrhovnom sudu RH. 
zemalja pokazale su pozitivne rezultate u odnosu na kvalitetu i učinkovitost suđenja.

$\mathrm{U}$ poredbenoj doktrini problematizirala se teza iura novit curia, u sklopu oglednoga postupka, koja nalaže da je u načelu i prvostupanjski sud jednako vezan pravom kao i Vrhovni sud pa kako sud ne funkcionira po, tzv. načelu administrativne subordinacije, ne bi trebao u prvostupanjskom postupku, kada je u dvojbi oko tumačenja prava, pitati za mišljenje Vrhovni sud. Dio doktrine smatra da iz toga proizlazi da nema pretpostavke o poznavanju prava te da se Vrhovni sud pita za mišljenje prije nego što bi pravna stvar preko odgovarajućih pravnih lijekova stigla do njega. U poredbenoj se doktrini kao sporan postavio i trenutak podnošenja pitanja Vrhovnom sudu, odnos u kojoj se fazi postupka pitanje postavlja. Ako je to u ranijoj fazi, tj. ako se činjenično stanje nije dostatno raspravilo, prvostupanjski sud nije u stanju zahtjevom se obraćati Vrhovnom sudu da on zauzme pravno stajalište, da procjeni radi li se stvarno o potrebi za novim (načelnim) pravnim stajalištima. Dakle, doktrina postavlja pitanje može li u stanju neraspravljenosti, prvostupanjski sud „prebaciti“ rješavanje slučaja Vrhovnom sudu. Umjesto da prvostupanjski sud napravi ono što mu je zadatak, na temelju tvrdnje da je riječ o novom slučaju, s navodnim ili stvarnim divergencijama stajališta nižestupanjskih sudova, raspravu, pod velom pravnog pitanja i tumačenja prava, s ostatkom neraspravljenih činjeničnih pitanja, ,prebacuje“ na Vrhovni sud. Također, ako je cilj parničnog postupka ubrzanje postupka, takvo hipotetično stanje nepotpune utvrđenosti činjenica vodi samo prividno do tog cilja. Štoviše, ako je cilj oglednog postupka da se Vrhovni sud rastereti omogućavajući mu da se posveti pravnim pitanjima, onda takva „prejudicijalna obraćanja“ prvostupanjskih sudova mogu poprilično zasmetati ostvarivanju toga cilja, jer bi pri zauzimanju pravnoga stajališta Vrhovni sud morao sagledati nedostatno raspravljeno činjenično stanje. Kao i u hrvatskom pravu, Vrhovni sud u povodu izvanrednih pravnih lijekova, u pravilu, ne raspravlja o činjeničnim pitanjima. To je "posao“ nižestupanjskih sudova, ali, volens nolens, on mora sagledati nedostatni činjenični supstrat, budući da je to preduvjet zauzimanja pravnoga stajališta. U raspravama se navodi, exempli causa, kako je moguće zamisliti situaciju da se Vrhovni sud izjasnio, da je zauzeo obvezujuće pravno stajalište. Prvostupanjski sud u skladu s tim, nastavlja i okončava postupak. Uzmimo $i$ to da je po pravomoćnosti tako završenoga postupka protiv takve odluke podnesen izvanredni pravni lijek, kojim se predmet ponovo našao pred Vrhovnim sudom. Hoće li tada Vrhovni sud (nakon što se već jednom izjasnio) odbaciti takav zahtjev na osnovi pravila ne bis in idem? Neće li se time obesmisliti institucija izvanrednoga pravnog lijeka? Nadalje, u doktrinarnim se raspravama ističe kako je postulat neovisnosti sudske vlasti u tome da su sudovi isključivo vezani zakonskim propisima, nisu vezani za mišljenje višeg tijela (poput administrativne vlasti). Zauzeto pravno stajalište višeg suda, naime, vezuje nižestupanjske sudove snagom argumentacije, a ne administrativne subordinacije. Štoviše, dio doktrine naznačuje kako je problem mnogo dublji i počiva na nedostatku razumijevanja koncepta vladavine prava onih koji postupaju po zahtjevima stranaka. Koncept vladavine prava, inter alia, podrazumijeva $i$ da je sud obvezan uzeti u obzir ne samo zakonsku normu koju je potrebno primijeniti u konkretnom slučaju, već i sve okolnosti slučaja koje mogu utjecati na činjenicu je li spomenutu normu potrebno jednostavno primijeniti na način kako je propisano, ili 
postoje li opravdani razlozi koji pružaju osnovu sudu da odstupi od njezinog sadržaja. Takva se mogućnost može crpiti i iz smisla Ustava i iz samoga zakona koji se primjenjuje i koji mora biti ne samo u skladu s Ustavom, već i tumačen u skladu s njim. Nijedan zakon ne zabranjuje sudu da, ako pronađe opravdani razlog, odstupi od zakonske norme pozivajući se na najviši pravni akt, a ESLJP je još davno uspostavio standard $\mathrm{u}$ tumačenju prava „dozvoljeno je sve što nije izričito zabranjeno”. U tim okolnostima, kada se sud nađe u situaciji da je očigledno da postoje opravdani razlozi da stranci omogući zaštititi svoje pravo, i pored činjenice da mu zakonska norma jasno ukazuje da bi, primjerice, zahtjev stranke trebalo odbaciti, on je dužan analizirati bit zakonske norme i razmotriti zahtjev stranke u postupku. U povodu navedenih prigovora Ustavni sud Republike Srbije je odlučivao ocijenivši kako navedene odredbe nisu neustavne. ${ }^{54}$ Inicijator ocjene ustavnosti odredaba o postupku za rješavanje spornog pravnog pitanja još je i zamjerio kako se ne osigurava dvostupanjski postupak suđenja, što je zajamčeno Ustavom. Prigovarao je da rješavanje spornoga pravnog pitanja Vrhovnog suda ne spada u izvore prava koje predviđa Ustav. Također se navodi i to da sporni postupak dovodi do neravnopravnoga položaja stranaka u onim predmetima u kojima se nižestupanjski sud nije obratio Vrhovnom sudu za prethodno rješavanje spornoga pravnog pitanja. ${ }^{55}$

\section{UMJESTO ZAKLJUČKA}

Ujednačenost sudske prakse znači poštivati načela pravne sigurnosti što podrazumijeva pretežno presuđivanje u skladu s prethodnim odlukama suda u slučajevima koji su isti ili bitno slični. Stoga je osiguravanje ujednačenja sudske prakse, sudeći po preporukama ESLJP-a, odlukama Ustavnog suda, i posljedično velikom angažmanu svih u pravosuđu (od ministarstva pravosuđa preko Visokog trgovačkog suda do Vrhovnog suda) jedan od prvorazrednih ciljeva u domaćem pravnom poretku. Iz svega rečenog zaključujemo da način na koji će se ujednačavati sudska praksa ovisi o velikom broju različitih čimbenika i njihovog kompleksnog i višesmjernog odnosa. U ovom se radu svakako ne iscrpljuju pitanja ujednačavanja sudske prakse, budući da se može samo ukazati na kompleksnost procesa sudačkog odlučivanja i djelomično sagledati zakonodavnu regulativu koja utječe na ujednačavanje sudske prakse.

Vraćajući se na osnovnu liniju argumentacije o problemu ujednačavanja sudske prakse vidimo kako je spomenuta presuda ESLJP-a u predmetu Nejdet Şahin $i$ Perihan Şahin protiv Turske možda i najvažniji predmet koji utvrđuje standarde koji

54 Službeni glasnik RS, br. 106/06 od 24. studenog 2006.

55 Vidi, Mato Tadić, ur., Pravo na obrazloženju sudsku odluku, Ustavni sud Bosne i Hercegovine, Sarajevo, 2018. Podrobnije na mrežnim stranicama: https://www.vk.sud.rs/sites/default/files/ attachments/POSTUPAK\%20ZA\%20RE\%C5\%A0AVANJE\%20SPORNOG\%20PRAVNOG\%20PITANJA\%20V.Popovi\%C4\%87.pdf te Borivoje Poznić i Vesna Rakić-Vodinelić, Građansko procesno pravo (Beograd: Savremena administracija, 2010.), 281 et seq.; Dragomir Milojević, Snežana Andrejević i Vesko Krstajić, Ujednačavanje sudske prakse - izazovi i moguća rješenja (Beograd: Misija OESSa u Srbiji, 2015.); Marija Salma, „Postupak za rješavanje spornog pravnog pitanja”, Zbornik radova Pravnog fakulteta u Novom Sadu, br. 1 (2012.): 289-298. 
ukazuju na povrede prava na pošteno suđenje zbog nedostatka pravne sigurnosti u pogledu neujednačene sudske prakse. Judikatura najviših sudova, kao što je i Vrhovni sud i Visoki trgovački sud, mora biti i jest dosljedna u najvećoj mogućoj mjeri te su novi procesno-pravni instituti iz ZPP-a, institut oglednog postupka te revizija po dopuštenju, po mišljenju autora funkcionalni mehanizmi koji omogućavaju ujednačenu primjenu pravnih normi, osiguravanje jedinstvene primjene prava i ravnopravnost svih u njegovoj primjeni. To pokazuje i praksa budući da je nedugo nakon stupanja na snagu, dana 15. listopada 2019. Vrhovni sud zaprimio prijedlog Općinskog suda u Pazinu pod nazivom Prijedlog za rješenje pitanja važnog za jedinstvenu primjenu prava - sporazum o konverziji ugovora o kreditu. ${ }^{56}$ Vezano za reviziju vjerujemo da će nakon početnih teškoća, koje su u ovakvim situacijama neminovne, stanje u ovom području biti sve bolje i da će, kada i sudska praksa odgovori na sporna pitanja koja će se sigurno pojaviti, prava vrijednost revizije po dopuštenju doći do izražaja.

Ipak sljedeći Ciceronovu maksimu Summum ius, summa iniuria, nužno je istaknuti kako judikatura ESLJP-a naznačuje kako zahtjevi pravne sigurnosti i zaštite legitimnog očekivanja ne daju stečeno i apsolutno pravo na dosljednost sudske prakse. ${ }^{57}$ Time ističe da bi propust u održavanju dinamičnog i evolucijskog pristupa riskirao kočenje reforme ili poboljšanj $\mathrm{a}^{58}$ te da se cilj pravne sigurnosti ipak mora slijediti uz poštovanje autonomije donošenja odluka i neovisnosti domaćih sudova. ${ }^{59}$ Razlog tomu treba tražiti u davanju prednosti ideji i konceptu „vladavine prava” u odnosu na koncept „,vladavine zakona” jer se nekritičkom primjenom zakona koja ne uzima u obzir okolnosti i činjenice u kojima se zakonske norme primjenjuju, nanosi „nepravda“ subjektima u postupku.

\section{LITERATURA}

Knjige i članci:

1. Barbić, Jakša i Marko Bratković, ur., Godišnjak Tribina Pravnog fakulteta Sveučilišta u Zagrebu i Kluba Pravnika grada Zagreba. Zagreb: Pravni fakultet, 2017.

2. Betetto, Nina. „Uloga slovenskoga Vrhovnog suda u ujednačavanju sudske prakse”. Zbornik Pravnog fakulteta u Zagrebu 68, br. 5-6 (2018.): 685-705.

3. Bratković, Marko. „Reforma revizije u parničnom postupku”. Hrvatska pravna revija 17, br. 2 (2017.): 79-94.

4. Bratković, Marko. Revizija po dopuštenju 2018., doktorska disertacija. Zagreb: Pravni fakultet, 2017.

5. Bratković, Marko. „Što je važno pravno pitanje u reviziji?”. Zbornik Pravnog fakulteta u Zagrebu 68, br. 5-6 (2018.): 853-880.

6. Dika, Mihajlo. „Marginalije uz prijedlog novog uređenja revizije u parničnom postupku (2018.)". Odvjetnik br. 3-4 (2018.): 21-30.

56 Svojim rješenjem Gos-1/2019 od 11. prosinca 2019. vijeće Vrhovnog suda RH dopustilo je prijedlog Općinskog suda u Pazinu za rješavanje pitanja važnog za jedinstvenu primjenu prava.

57 Exempli causa, Unedic protiv Francuske, odluka, 18. prosinca 2008., br. 20153/04.

58 Vidjeti, exempli causa, Atanasovski protiv Bivše Jugoslavenske Republike Makedonije, odluka 14. siječnja 2010., br. 36815/03.

59 U skladu sa stajalištem izraženim u odluci Nejdet Şahin i Perihan Şahin protiv Turske, br. 13279/05, 20. studeni 2011. 
7. Dika, Mihajlo i Ivana Martinović. Analiza uticaja odluka Ustavnog suda Crne Gore na sistem redovnih sudova sa posebnim osvrtom na odnos Ustavnog $i$ Vrhovnog suda Crne Gore. Strasbourg: Savjet Evrope, 2018.

8. Garašić, Jasnica. „Osvrt na novopredložene odredbe o reviziji u parničnom postupku u 18. nacrtu prijedloga Zakona o izmjenama i dopunama Zakona o parničnom postupku”. Odvjetnik, br. 3-4 (2018.): 37-59.

9. Katić, Dragan. „O revizijama i noveliranju Zakona o parničnom postupku”. Odvjetnik br. 3-4 (2018.): 60-64.

10. Milojević, Dragomir, Snežana Andrejević i Vesko Krstajić. Ujednačavanje sudske prakse - izazovi i moguća rješenja. Beograd: Misija OESSa u Srbiji, 2015.

11. Nakić, Jakob. „(Izvanredna) revizija po Zakonu o parničnom postupku na razmeđi?”. U: Aktualnosti hrvatskog zakonodavstva i pravne prakse, tradicionalno XXXIII. Savjetovanje, Hrvatsko društvo za građansko pravne znanosti i praksu, Godišnjak 25, 263-270. Zagreb: Organizator, 2018.

12. Poznić, Borivoje i Vesna Rakić-Vodinelić. Građansko procesno pravo. Beograd: Savremena administracija, 2010.

13. Rajko, Alen. „Odnos predsjednika suda sa sudskim strankama - pravno uređenje i pitanja iz prakse". Zbornik Pravnog fakulteta Sveučilišta u Rijeci 40, br. 1 (2019.): 573-587.

14. Salma, Marija. „Postupak za rješavanje spornog pravnog pitanja”. Zbornik radova Pravnog fakulteta u Novom Sadu, br. 1 (2012.): 289-298.

15. Šagovac, Antun. „Stranputice revizije prema Nacrtu prijedloga Zakona o izmjenama i dopunama Zakona o parničnom postupku". Novi informator br. 6565 (2019.): 2-3.

16. Tadić, Mato, ur. Pravo na obrazloženu sudsku odluku. Sarajevo: Ustavni sud Bosne i Hercegovine, 2018., https://www.vk.sud.rs/sites/default/files/attachments/POSTUPAK \%20ZA\%20RE\%C5\%A0AVANJE\%20SPORNOG\%20PRAVNOG\%20PITANJA\%20 -V.Popovi \%C4\%87.pdf

17. VHS. Pristup 13. studeni 2019. http://www.vsrh.hr/EasyWeb.asp?pcpid=2152

18. Vijeće Evrope/Europski sud za ljudska prava, Vodič kroz čl. 6. Konvencije - Pravo na pravično suđenje (građanskopravni aspekt), 2018. Pristup 13. studeni 2019. www.echr. coe.int

19. Vujičić, Božidar. „Ujednačavanje sudske prakse u građansko pravnoj materiji - problemi i moguća rješenja”. Bilten Vrhovnog Kasacijskog suda br. 3 (2012.): 263-276.

Hrvatski pravni propisi:

1. Ustavni sud, U-III - 354/2016 od 30. ožujka 2017.

2. Ustavni sud, U-III - 354/2016 od 30. ožujka 2017.

3. Ustavni zakon o Ustavnom sudu Republike Hrvatske, Narodne novine, br. 99/99., 29/02., $49 / 02$.

4. Vrhovni sud RH, Gos-1/2019 od 11. prosinca 2019.

5. Zakon o parničnom postupku, Narodne novine, br. 53/91., 91/92., 58/93., 112/99., 88/01., 117/03., 88/05., 02/0.7, 84/08., 96/08., 123/08., 57/11., 148/11., 25/13., 89/14., 70/19.

6. Zakon o područjima u i sjedištima sudova, Narodne novine, br. 67/18.

7. Zakon o sudovima, Narodne novine, br. 28/13., 33/15., 82/15., 82/16., 67/18.

8. Zakon o upravnim sporovima, Narodne novine, br. 20/10., 143/12., 152/14., 94/16., 29/17.

9. Županijski sud u Vukovaru, Gž-465/18 od 22. kolovoza 2018.

Propisi drugih država

1. Zakon o parničnom postupku Federacije Bosne i Hercegovine, Službene novine Federacije BiH, br. 53/03., 73/05., 19/06. te 98/15.

2. Zakon o parničnom postupku, Službeni glasnik RS, br. 72/11., 49/13. - odluka US, 74/13. - odluka US, 55/14. i 87/18. 
3. Zakon o pravdnem postopku, Ur. list RS, št. 73/07 - uradno prečiščeno besedilo, 45/08 - ZArbit, 45/08, 111/08 - odl. US, 57/09 - odl. US, 12/10 - odl. US, 50/10 - odl. US, 107/10 - odl. US, 75/12 - odl. US, 40/13 - odl. US, 92/13 - odl. US, 10/14 - odl. US, 48/15 - odl. US, 6/17 - odl. US, 10/17 in 16/19 - ZNP-1

Sudska praksa Europskog suda za ljudska prava

1. Albu i drugi protiv Rumunjske, presuda, 10. svibnja 2012., br. 34796/09

2. Atanasovski protiv „Bivše Jugoslovenske Republike Makedonije”, presuda, 14. siječnja 2010., br. 36815/03,

3. Brezovec protiv Hrvatske, presuda, 29. ožujka 2011., br. 13488/07

4. Brualla Gómez de la Torre protiv Španjolske, presuda, 19. prosinca 1997., br. 26737/95

5. Grkokatolička župa Lupeni i drugi protiv Rumunjske, presuda, 29. studeni 2016., br. 76943/11

6. Hirvisaari protiv Finske, presuda, 27. rujna 2001., br. 49684/99

7. Iordan Iordanov $i$ ostali protiv Bugarske, presuda, 2. srpnja 2009. br. 23530/02

8. Issyar protiv Bugarske, presuda, 20. studeni 2008., br. 391/03

9. Kuchoglu protiv Bugarske, presuda, 10. svibnja 2007., br. 48191/99

10. Marckx protiv Belgije, presuda, 13. lipnja 1979., br. 6833/74

11. Mullai i ostali protiv Albanije, presuda, 23. ožujka 2010., br. 9074/07

12. Nejdet Şahin i Perihan Şahin protiv Turske, presuda, 20. listopada 2011., br. 13279/05

13. Santos Pinto protiv Portugala, presuda, 20. svibnja 2008., br. 39005/04

14. Tudor Tudor protiv Rumunjske, presuda, 24. ožujka 2009., br. 21911/03

15. Unédic protiv Francuske, presuda, 18. prosinca 2008., br. 20153/04

16. Vidaković protiv Crne Gore, presuda, 24. svibnja 2016., br. 27524/06

17. Vrioni i ostali protiv Albanije, presuda, 24. ožujka 2009., br. 2141/03

18. Zubac protiv Hrvatske, presuda, 5. travnja 2018., br. 40160/12. 


\author{
Dejan Bodul* \\ Jelena Čuveljak** \\ Sanja Grbić****
}

Summary

\title{
(MORE) ABOUT UNIFORMING COURT PRACTICE IN CIVIL CASES
}

The ideal of civil litigation is a high degree of predictability, which is nothing but a stable and consistent case law. Specifically, citizens and businesses that go to court for identical factual circumstances must receive the same verdict, and courts of one state must handle identical legal issues in the same way, no matter where they are situated. On the other hand, at the heart of the legal standard of judicial independence is the freedom of the individual judge from all influences that would prevent him from making decisions ex lege, on the basis of his conscience and in concreto when resolving specific cases. So, if there are few, if any, practitioners, theorists, and lawmakers who would not want a greater degree of uniform case law, going down to the empirical level, we see that ensuring consistent application of the law in practice is an extremely demanding job. Although different methodological approaches are available in studying this complex problematic issue, efforts have been directed towards analysing positive solutions as well as ECHR practices, all for possible suggestions.

Keywords: standardization of practice; new Civil Procedure Act; Art. 6. ECHR.

Zusammenfassung

\section{(NOCH) ÜBER DIE HARMONISIERUNG DER RECHTSPRECHUNG IN ZIVILSACHEN}

Das Ideal des Gerichtsverfahrens ist ein hohes Maß an Vorhersehbarkeit, was eigentlich eine stabile und harmonisierte Rechtsprechung ist. Den Bürgern und Geschäftssubjekten, die vor Gericht wegen identischer tatsächlicher Umstände treten, muss das gleiche Urteil ausgesprochen werden und die Gerichte eines Staates müssen

* Dejan Bodul, Ph.D., Assistant Professor, University of Rijeka, Faculty of Law; dbodul@pravri. $\mathrm{hr}$.

** Jelena Čuveljak, Ph.D., Judge, High Commercial Court of the Republic of Croatia; jelena. cuveljak@gmail.com

*** Sanja Grbić, Ph.D., Assistant Professor, University of Rijeka, Faculty of Law; sgrbic@pravri. hr. 
ungeachtet ihrer Sitze identische rechtliche Fragen auf die gleiche Art und Weise lösen. Die Basis des Rechtsstandards der Unabhängigkeit der rechtsprechenden Gewalt ist die Unabhängigkeit des individuellen Richters von allen Einflüssen, die ihn verhindern würden, nur ex lege, aufgrund seines Gewissens und in concreto (bei der Beilegung konkreter Rechtsgegenstände) zu entscheiden. Obwohl es sehr wenige (falls es sie überhaupt gibt) Praktiker, Theoretiker und Gesetzgeber gibt, die nicht wollen, dass die Rechtsprechung unter Ceteris Paribus-Bedingungen stärker harmonisiert wird, ist die Sicherung der einheitlichen Gesetzesanwendung in der Praxis sehr anspruchsvoll. Obwohl es unterschiedliche methodologische Ansätze für diese Problemfrage gibt, versucht dieser Beitrag, die positivrechtlichen Beschlüsse und die Rechtsprechung des EGMR zu analysieren, alles mit dem Ziel, mögliche Vorschläge zu geben.

Schlüsselwörter: Harmonisierung der Rechtsprechung; neue Zivilprozessordnung; Art. 6 der EMRK.

Riassunto

\section{(ANCORA) DELL' UNIFORMAZIONE DELLA PRASSI NELLA GIURISPRUDENZA CIVILE}

L'ideale del processo civile è rappresentato da un alto grado di prevedibilità, il che non è nient'altro che una stabile e coesa prassi giudiziaria. In particolare, i cittadini e gli imprenditori che vanno davanti alla corte per le stesse circostanze fattuali devono ottenere la stessa sentenza; mentre le corti di uno stato devono risolvere nello stesso modo i casi con identiche questioni legali, indipendentemente da dove esse siano situate. D'altra parte, nelle fondamenta dello standard legale dell'indipendenza delle autorità giudiziarie si trova la libertà del singolo giudice rispetto a tutti gli impatti che lo ostacolerebbe a portare la decisione unicamente ex lege, sulla base della sua coscienza ed in concreto quando è chiamato a risolvere casi specifici. Quindi, visto che sono pochi, ammesso che ci siano, gli operatori giudiziari, i teorici e i creatori del pensiero giuridico, i quali ceteris paribus non auspicherebbero un maggiore grado di uniformazione della giurisprudenza, scendendo sul piano empirico, vediamo che la garanzia dell'applicazione consistente di leggi è un lavoro estremamente duro nella prassi. Benché già vi siano diversi approcci metodologici per studiare la complessità di questa problematica, ulteriori sforzi devono essere diretti all'analisi di soluzioni positive, come quelle della prassi della Corte EDU e tutto ciò con lo scopo di giungere a nuove soluzioni.

Parole chiave: uniformazione della giurisprudenza; nuova Legge sul processo civile; art. 6 della CEDU. 